\title{
PENGEMBANGAN MODUL PEMBELAJARAN DINAMIKA GERAK BERBASIS INKUIRI TERBIMBING UNTUK SISWA KELAS X SMA/MA
}

\author{
Enik Setianingsih $^{1}$, Widha Sunarno ${ }^{2}$ dan Sukarmin ${ }^{3}$ \\ ${ }^{1}$ Program Studi Magister Pendidikan Sains FKIP Universitas Sebelas Maret \\ Surakarta, 57126, Indonesia \\ eniksetianingsihl@student..uns.ac.id \\ ${ }^{2}$ Program Studi Magister Pendidikan Sains FKIP Universitas Sebelas Maret \\ Surakarta, 57126, Indonesia \\ widhasunarno@staff.uns.ac.id \\ ${ }^{3}$ Program Studi Magister Pendidikan Sains FKIP Universitas Sebelas Maret \\ Surakarta, 57126, Indonesia \\ karmin.abdulkarim@staff.uns.ac.id
}

\begin{abstract}
Abstrak
Pada saat memasuki belajar konsep fisika yang baru, siswa tidak datang dengan pikiran kosong tanpa memiliki pengetahuan awal, siswa biasanya telah memiliki wawasan dari pengalaman sehari-hari dan informasi sekitar. Kadang-kadang konsep awal yang telah di bangun siswa tidak sesuai dengan dengan konsep ilmu yang sudah di sepakati oleh para ahli. Keadaan demikian disebut dengan miskonsepsi. Penelitian pengembangan ini bertujuan untuk mengetahui:(1)karakteristik modul pembelajaran berbasis inkuiri terbimbing untuk penurunan miskonsepsi pada materi dinamika gerak untuk siswa SMA kelas X, (2) kelayakan modul pembelajaran berbasis inkuiri untuk menurunkan miskonsepsi pada materai mekanika dinamika gerak untuk siswa SMA kelas X, (3) Ada penurunan miskonsepsi fisika setelah di beri modul pembelajaran berbasis inkuiri terbimbing pada materi dinamika gerak untuk siswa SMA kelas $X$. Penelitian menggunakan metode pengembangan $(R \& D)$ yang mengacu pada model yang dikemukakan oleh Thiagarajan, yang dilaksanakan dari bulan Juli 2015 hingga Mei 2016. Kelayakan media divalidasi oleh ahli materi dan ahli media, validasi guru, dan validasi teman. Subjek uji coba penelitian ini adalah siswa kelas X SMAN 2 Jombang tahun akademik 2015/2016 sebanyak 34 siswa dengan rincian 10 siswa sebagai subjek uji coba terbatas dan 30 siswa sebagai subjek uji coba pemakaian. Modul disebarkan pada guru-guru fisika SMA. Data hasil penelitian berupa nilai validasi modul oleh ahli, guru dan teman sejawat, respon keterbacaan siswa, dan hasil penurunan miskonsepsi dengan menggunakan uji t-test paired two sample for mean menggunakan software SPSS 18. Penelitian pengembangan yang telah dilaksanakan memberikan kesimpulan : (1) langkah-langkah prosedur pengembangan yang dilakukan untuk mengembangkan modul fisika berbasis inkuiri terbimbing materi dinamika gerak menggunakan model 4-D yang diawali tahap 1 define yaitu melakukan studi literatur yang meliputi analisis siswa, kurikulum dan materi, tahap 2 design yaitu pemilihan format modul, tahap 3 develop yaitu desain awal modul, validasi produk, uji coba terbatas, perbaikan, uji coba luas, dan tahap 4 disseminate yaitu penyebaran modul pada guru fisika SMA. Pengembangan yang dilakukan mengacu pada langkah yang dinyatakan oleh Thiangarajan dan telah tervalidasi; (2) modul fisika berbasis inkuiri terbimbing materi dinamika gerak untuk siswa kelas X SMA yang dikembangkan dinyatakan layak dengan kategori sangat baik; (3) Ada penurunan miskonsepsi fisika setelah diberi modul berbasis inkuiri terbimbing pada materi dinamika gerak.
\end{abstract}

Kata kunci: Miskonsepsi, Modul Fisika, Inkuiri Terbimbing

Pendahuluan

Pada saat memasuki tahap konsep fisika yang baru, siswa tidak datang dengan pikiranyan kosong tanpa memiliki pengetahuan awal. Siswa biasanya telah memiliki wawasan dari pengalaman seharihari dan informasi dari lingkungan sekitar. 
Dalam pengalaman tersebut terbentuk prakonsepsi atau sejenis "teori siswa" mengenai peristiwa-peristiwa fisika dalam lingkungan sehari-hari manusia. Prakonsepsi ini belum tentu benar, Jika dalam proses pembelajaran guru tidak memperhatikan prakonsepsi, maka dalam kepala siswa akan terjadi percampuran prakonsepsi dengan konsep yang sebenarnya. Percampuran ini akan menyebabkan pengertian yang salah dalam diri siswa (Berg ,1990).

Mengingat Siswa sendiri yang mengkonstruksikan pengetahuannya, maka tidak mustahil dapat terjadi kesalahan dalam mengkonstruksi. Kadang-kadang konsep awal yang telah dibangun siswa tidak sesuai dengan konsep ilmiah yang sudah disepakati oleh para ahli. Keadaan demikian disebut dengan miskonsepsi. Miskonsepsi tersebut biasanya sulit diatasi karena siswa cenderung mempertahankan konsep awal ini secara kokoh (Ibrahim, 2012).

Pelajaran fisika, sangat rentang mengalami miskonsepsi. Miskonsepsi biasanya menyangkut kesalahan siswa dalam pemahaman hubungan antar konsep atau juga pada beberapa bagian dalam konsep, misalnya dalam mekanika, termodinamika, kalor, optika geometri, bunyi dan gelombang, listrik dan magnet, dan fisika modern (Suparno, 2005 dan Berg, 1991).

Selain itu banyak siswa yang berpendapat bahwa fisika sulit untuk dipelajari karena hanya merupakan kumpulan rumus-rumus belaka yang kurang dapat dimengerti maknanya. Pendapat ini muncul karena kebiasaan belajar fisika siswa yang berorientasi pada rumus-rumus dan pembahasan soal secara langsung tanpa mempelajari konsep-konsepnya. Sehingga siswa hanya menghafal rumus dan hanya terampil melakukan perhitungan tanpa mengerti makna konsep yang dipelajari. Kesulitan-kesulitan dalam memahami konsep fisika ini akan menyebabkan terjadinya miskonsepsi. Kesalahankesalahan yang terjadi pada buku teks dapat menimbulkan pemahaman konsep yang salah pada diri siswa. Selain kesalahan yang terdapat pada buku teks, sering kali siswa mengalami kesulitan dalam memahami tulisan yang terdapat pada buku teks, serta terdapat juga buku fiksi sain yang konsepnya menyimpang demi menarik pembaca. Hal-hal negative yang terdapat pada buku teks tersebut dapat menyebabkan terjadinya miskonsepsi.

Dari beberapa fakta di atas terlihat bahwa terdapat beberapa faktor penyebab miskonsepsi. Menurut Paul Suparno (2005). Secara umum penyebab miskonsepsi ada lima kelompok yaitu siswa, guru, buku teks, kontek dan cara mengajar.

Sebagai contoh miskonsepsi pada materi Dinamika gerak. Sebuah tes pendahuluan diberikan kepada siswa SMAN 2 Jombang yang telah menerima pelajaran tentang materi ini pada SMA kelas X dan SMP kelas VII akhirnya masih didapatkan kesalahan-kesalahan pemahaman siswa sebagai berikut, (1) Benda diam, berarti tidak ada gaya. (2) Agar benda bergerak dengan kecepatan tetap, harus ada gaya resultan dengan besar yang tetap ( > 0) dan arah sejajar dengan gerak benda,. (3) Gaya normal sama dengan gaya berat. (4) kecepatan hanya akan bertambah jika gaya resultan pada benda bertambah

Pembelajaran inkuiri terbimbing merupakan pembelajaran yang menggunakan cara pengumpulan informasi yang relevan dan menggunakan analisis logis melalui penyelidikan, serta investigasi fenomena sekitar dengan arahan, petunjuk yang berupa pertanyaan membimbing, sehingga siswa menyelesaikan permasalahan berdasarkan fakta yang ditemukan (Joyce\&Weil,2000).Inkuiri terbimbing merupakan pembelajaran yang mengarahkan siswa melakukan penyelidikan untuk memperoleh dan mendapatkan informasi melalui observasi/eksperimen untuk mencari jawban atau memecahkan masalah

Pembelajaran inkuiri terbimbing memiliki ciri-ciri; a) Menggunakan 
keterampilan proses; b) Jawaban yang dicari siswa tidak diketahui terlebih aktif dahulu; c) Siswa bersemangat untuk memecahkan masalah; d) Siswa menemukan solusi secara individu; e) Siswa mengusulkan cara-cara pengumpulan data dan pengamatan data; f) Hipotesis dirumuskan oleh siswa; g) Siswa melakukan penelitian secara individu/kelompok untuk menggumpulkan data untuk menguji hipotesis; h) Siswa mengolah data sampai menemukan kesimpulan

Menurut Hamdani ( 2011 : 120), Bahan ajar adalah segala bentuk bahan atau materi yang disusun secara sistematis yang di gunakan untuk membantu guru atau instruktur dalam melaksanakan kegiatan belajar mengajar sehingga tercipta lingkungan atau suasana yang memungkinkan siswa untuk belajar. Selanjutnya menurut Daryanto ( 2013: 9) "Modul merupakan salah satu bentuk bahan ajar yang dikemas secara utuh dan sistematis, didalamnya memuat seperangkat pengalaman belajar yang terencana dan didesain untuk membantu peserta didik menguasai tujuan belajar yang spesifik" Menurut Depdiknas (2008), mendefinisikan modul sebagai alat atau sarana pembelajaran yang berisi materi, metode, batsan-batasan, dan secara mengevaluasi yang di rancang secara sistematis dan menarik untuk mencapai kompetensi yang diharapkan sesuai dengan kompleknya. Sedangkan Nasution ( 2003 : 205), mengemukakan modul dapat dirumuskan sebagai suatu unit yang lengkap yang berdiri sendiri dan terdiri atas suatu rangkaian kegiatan belajar yang disusun untuk membantu siswa mencapai sejumlah tujuan yang di rumuskan secara khusus dan jelas.

Berdasarkan pendapat di atas dapat disimpulkan bahwa modul merupakan suatu alat atau sarana pembelajaran yang didalam berupa materi, metode, dan evaluasi yang dibuat secara sistematis dan terstruktur sebagai upaya untuk mencapai tujuan kompetensi yang diharapkan. Modul dirancang secara khusus dan jelas berdasarkan kecepatan pemahaman masingmasing siswa, sehingga mendorong siswa untuk belajar sesuai dengan kemampuannya.

Modul berbasis inkuiri terbimbing merupakan suatu rangkaian kegiatan belajar yang melibatkan secara maksimal seluruh kemampuan siswa untuk menganalisis, memecahkan permasalan berdasarkan fakta-fakta yang ditemukan dan didesain untuk mendapatkan pemahaman konseptual. Modul inkuiri terbimbing menggunakan sintaks inkuiri terbimbing: 1) observasi; 2) Merumuskan masalah; 3) Mengidentifikasi masalah; 4) membuat kesimpulan.

\section{Metode Penelitian}

Jenis penelitian yang digunakan adalah jenis penelitian pengembangan atau Research and Develoment (R\&D) yaitu penelitian yang menghasilkan suatu produk tertentu. Desain yang digunakan sebagai dasar untuk mengembangkan modul berbasis inkuiri terbimbing ini adalah model 4-D (four-D model) yang dikemukakan oleh Thiagarajan) Langkahlangkah pengembangan modul fisika berbasis inkuiri terbimbing ini menggunakan model 4-D (define, design, develop and dessiminate).

1. Pendefinisian (Define)

Tahap pendahuluan penelitian bertujua untuk menentukan dan mendefinisikan kebutuhan-kebutuhan pembelajaran di SMAN 2 Jombang, terutama pada kelas X. Termasuk mengidentifikasi karakteristik siswa dan kondisi sekolah. Identifikasi potensi dan masalah yang ada dalam pembelajaran khususnya pembelajaran fisika. Temuan-temuan yang diperoleh dijadikan dasar langkah untuk perancangan produk yang akan dibuat.

Tahap pendahuluan dilakukan di SMAN 2 Jombang yang dijadikan tempat penelitian sehingga dapat ditemukan masalah-masalah yang ada pada sekolah tersebut. Observasi dilakukan dengan wawancara baik pada 
guru fisika kelas $\mathrm{X}$ maupun pada siswa, pengamatan langsung, serta meggunakan angket kebutuhan terhadap guru bidang studi fisika dan siswa di sekolah tempat penelitian.

Masalah yang ditemukan dijadikan dasar untuk merancang bahan ajar yang dapat membantu siswa dalam belajar. Maka pada penelitian ini dikembangkan modul berbasis inkuiri terbimbing dengan berpedoman pada kompetensi inti dan kompetensi dasar fisika kurikulum 2013, materi pokok pada pengembangan ini yaitu dinamika gerak. Meningkatkan pemahaman konsep dan matematis pada materi dinamika gerak serta meningkatkan kemampuan siswa dalam mengaplikasikan konsep pada kehidupan sehari-hari maka diperlukan pengembangan modul yang memuat tentang konsep, besaran-besaran dinamika gerak secara metematis serta aplikasi dalam kehidupan sehari-hari. Pengembangan modul tersebut diharapkan dapat membantu proses belajar siswa menjadi terorganisir sehingga siswa lebih mudah memahami konsep yang diberikan melalui pengembangan modul, dan akan diperoleh modul pembelajaran yang mampu menjawab permasalahan yang dihadapi siswa.

\section{Perancangan (Design)}

Desain produk merupakan tahap mengembangkan modul pembelajaran fisika berbasis inkuiri terbimbing, yang didalamnya menjabarkan materi dengan menggunakan tahapan-tahapan sesuai dengan tahapan inkuiri terbimbing. Modul fisika berbasis inkuiri terbimbing berisi pemfokusan pada masalah yaitu fenomena dalam kehidupan sehari-hari sebagai tahapan awal, kemudian penjabaran aspek secara fisika dari fenomena di awal pembelajaran, rencana pemecahan masala yang berisi kegiatan perancangan/rencana penyelesaian masalah dari siswa untuk menyelesaikan masalah dalam kegiatan inkuiri terbimbing, melakukan eksperimen yaitu berisi kegiatan eksperimen fisika yang melatih sikap ilmiah siswa, kejujuran, dan objektivitas siswa, dalam kegiatan ini siswa menjalankan rencana penyelesaian masalah yang telah direncanakan. Kegiatan ini diharapkan mampu membiasakan siswa terlibat dalam proses penyelesaian masalah dalam kegiatan inkuiri terbimbing Kemudian dilanjutkan mengevaluasi jawaban yaitu berisi kegiatan evaluasi jawaban pertanyaan/permasalahan yang ingin diselesaikan. Kegiatan ini dilakukan untuk mengetahui hasil yang diperoleh telah sesuai, lengkap dan menjawab masalah. Disetiap akhir pembelajaran terdapat tes kemanpuan awal miskonsepsi yang bertujuan mengetahui seberapa besar konsep yang dikuasai siswa, dan terdapat pemahaman konsep yang berisi materimateri terkait dengan pembelajaran.

Selanjutnya produk awal berupa draft 1 modul fisika berbasis inkuiri terbimbing diserahkan kepada ahli untuk dilakukan validasi. Validasi dilakukan untuk mengetahui kesahihan atau kevalidan isi dan format modul dari sebuah instrumen berdasarkan kriteria tertentu. Proses validasi melibatkan ahli materi dan media, guru fisika, dan teman sejawat (peer review). Validasi ahli meliputi ahli media dan ahli materi fisika. Validasi ahli materi dan media ini untuk mengetahui kebenaran isi dan format modul fisika berbasis inkuiri terbimbing yang dikembangkan. Validasi guru meliputi dua guru, yaitu dua guru fisika SMA yang bertujuan untuk mengetahui kemungkinan keterlaksanan pembelajaran menggunakan modul fisika berbasis inkuiri terbimbing. Sedangkan validasi teman sejawat (peer review) terdiri dari dua mahasiswa. Validasi peer review bertujuan untuk mengetahui keterbacaan materi dan format. Validasi produk dilakukan dengan menggunakan instrumen lembar validasi kegrafikan, lembar validasi kelayakan isi dan lembar validasi kisi-kisi soal, setiap instrumen terdapat penilaian serta kolom saran/koreksi. Hasil validasi ini menghasilkan produk draft II modul fisika berbasis inkuiri terbimbing.

3. Pengembangan (Develop)

Draft II yang dihasilkan, uji coba terbatas digunakan untuk mengetahui 
tingkat keterbacaan modul fisika berbasis inkuiri terbimbing yang dikembangkan. Hal ini menjadi dasar yang digunakan untuk mengetahui kelemahan modul yang akan digunakan sebagai acuan untuk refisi sehingga didapatkan draf III yang siap diuji coba pemakaian. Uji coba ini dilakukan oleh 10 siswa kelas $X_{5}$ yang diambil berdasarkan peringkat 1 sampai 10. Siswa membaca dan mempelajari modul berbasis inkuiri terbimbing yang dikembangkan, kemudian mengisi angket keterbacaan. Hal tersebut dilakukan untuk memperoleh saran terkait modul pembelajaran yang dikembangkan.

Hasil uji coba terbatas memungkinkan perlu adanya revisi. Hasil revisi berupa produk draft III yang akan digunakan untuk uji coba diperluas.

Hasil revisi uji coba terbatas digunakan dalam proses pembelajaran pada sampel lebih besar yaitu siswa-siswi kelas X6. Uji coba besar atau pemakaian bertujuan untuk mengetahui penurunan miskonsepsi siswa setelah mengikuti proses pembelajaran dengan menggunakan modul fisika berbasis inkuiri terbimbing. Desain yang digunakan dalam penelitian pengembangan modul fisika berbasis inkuiri terbimbing ini adalah Pre Experimental Design dengan bentuk One Group Pretest-Postest Design. seperti pada Tabel 1 berikut.

Tabel 1. Bagan one-group pretes - posttest

\begin{tabular}{ccccc}
\hline & Grup & Pretes & $\begin{array}{c}\text { Variabel } \\
\text { terikat }\end{array}$ & Postes \\
\hline R $\quad$ Eksperimen & $\mathrm{O}_{1}$ & $\mathrm{X}$ & $\mathrm{O}_{2}$ \\
\hline
\end{tabular}

Keterangan:

O1 : Profil miskonsepsi sebelum perlakuan

$\mathrm{O} 2$ : Profil miskonsepsi sesudah perlakuan

$\mathrm{X}$ : Jenis perlakuan/treatment

\section{Penyebaran (Desseminate)}

Penyebaran dilakukan ke beberapa guru fisika SMA di Jombang. Sehingga produk modul fisika berbasis inkuiri terbimbing. dapat tersebar dan digunakan oleh guru-guru fisika SMA. Guru juga diminta mengisi angket yang hasilnya sebagai respon guru terhadap modul fisika berbasis inkuiri terbimbing.

Subyek penelitian terdiri dari dua golongan yaitu: subyek ahli/pakar yang terdiri dari subjek analisis kebutuhan, ahli media, ahli materi, praktisi dan teman sejawat. Subjek coba (user) dalam penelitian dan pengembangan ini yaitu peserta didik kelas $\mathrm{X}$ semester satu siswa SMA N 2 Jombang tahun pelajaran 2015/2016. Teknik penentuan sampel dilakukan dengan pertimbangan tertentu, sampel ini lebih cocok digunakan pada penelitian deskriptif (Sugiyono, 2012).

Jenis data yang dikumpulkan dalam proses penelitian dan pengembangan ini adalah jenis data kualitatif dan data kuantitatif. Data berupa hasil analisis kebutuhan, data hasil validasi ahli, data hasil uji coba produk, dan uji coba pemakaian yang berupa masukan, tanggapan, kritik, saran, serta perbaikan terhadap produk. Data yang diperoleh dalam tahap validasi dan uji coba berfungsi untuk memberi masukan dalam merevisi serta menilai kelayakan modul pembelajaran yang dikembangkan.

Instrumen yang digunakan dalam penelitian ini berupa instrumen angket dan soal tes. Angket dalam penelitian ini digunakan untuk mengumpulkan data tentang kelayakan modul fisika berbasis inkuiri terbimbing yang dikembangkan ditinjau dari aspek materi dan aspek media. Menurut Arifin (2012: 118), angket termasuk alat untuk mengumpulkan dan mencatat data atau informasi, pendapat, dan paham dalam hubungan kausal. Instrumen tes digunakan untuk mengetahui pemahaman siswa terhadap materi setelah mengikuti proses pembelajaran. Budiyono (2011: 8) menyatakan, tes merupakan seperangkat pertanyaan yang disetiap butir pertanyaan mempunyai jawaban yang dianggap benar. Agar diperoleh data yang valid, tes yang digunakan untuk evaluasi harus valid. Tes yang valid berarti tes yang digunakan untuk mendapatkan data (mengukur) itu valid. Valid berarti tes 
tersebut dapat digunakan untuk mengukur apa yang seharusnya diukur (ketepatan).

Analisis data dan uji coba pengembangan produk terdiri dari analisis kualitatif dan analisis kuantitatif. Hasil tes berupa data pretest, posttest, dan Uji-t Paired two sample for mean digunakan untuk mengetahui pengaruh modul pembelajaran terhadap penurunan miskonsepsi siswa pada materi yang diajarkan. Data yang diperoleh dari hasil uji coba produk di kelas dikonversikan menjadi nilai dengan menggunakan persamaan (Riduwan, 2004) yaitu

Retercapaiannilai $=\frac{\sum \text { jawaban benar }}{\sum \text { soal }} \times 100$

Analisis penurunan miskonsepsi dapat diketahui berdasarkan uji-t paired two sample for mean, bila Pearson Correlation berharga negatif ada penurunan miskonsepsi,dan

Teknik analisis data hasil validasi untuk kelayakan produk dilakukan dengan menggunakan perhitungan rating scale Sugiyono (2011) menyatakan bahwa rating scale lebih fleksibel, tidak terbatas untuk mengukur sikap saja tetapi juga dapat digunakan untuk mengukur persepsi responden terhadap fenomena lainnya, seperti mengukur status sosial, ekonomi kelembagaan, pengetahuan, kemampuan, proses kegiatan dan lain-lain. Langkah analisis data menggunakan perhitungan rating scale dalah sebagai berikut:

1) Tabulasi semua data yang diperoleh untuk setiap komponen, sub komponen dari butir penilaian yang tersedia dalam instrumen penilaian

2) Menghitung skor hasil pengumpulan data

3) Menentukan skala pada perhitungan rating scale dengan persamaan sebagai berikut:

Skorideal $=\mathrm{ST}_{\text {tiap butir }} \times \mathrm{JI} \times \mathrm{JR}$.

\section{Hasil Penelitian dan Pembahasan}

Hasil dari setiap tahapan prosedur pengembangan yang dilakukan adalah:

1. Tahap Pendefinisian (Define)

Kegiatan penelitian dan

pengembangan pada tahap 1 yaitu pendefinisian yang meliputi analisis kebutuhan. Analisis kebutuhan dilakukan untuk mengumpulkan informasi tentang kebutuhan modul guru sebagai alternatif untuk panduan mengajar atau menyusun skenario pembelajaran. Analisis kebutuhan ini dilakukan menggunakan angket kebutuhan siswa dan angket kebutuhan guru, yang melibatkan enam siswa dan dua guru mata pelajaran fisika.

Berdasarkan hasil analisis angket pengungkap kebutuhan guru dan siswa serta observasi yang dilakukan diperoleh kesimpulan bahwa diperlukan modul pembelajaran fisika untuk membantu siswa dalam memahami materi.

Tahap selanjutnya dilakukan analisis peserta didik, kurikulum dan materi. Berdasarkan keterangan guru, siswa memiliki kemampuan yang masih kurang. Pengamatan buku ajar yang digunakan siswa, diketahui bahwa buku yang digunakan siswa dalam proses pembelajaran yaitu LKS yang hanya sedikit memuat ringkasan materi. Siswa yang menggunakan buku penunjang lain jumlahnya sedikit. Buku-buku yang digunakan sepenuhnya belum menunjang siswa dalam belajar sehingga siswa kurang termotivasi. Hal ini sesuai menurut Hamdani (2011) bahwa belajar terjadi ketika ada interaksi antara individu dengan lingkungan, dapat juga berupa buku untuk memotivasi siswa. Dengan demikian buku ajar yang kurang menunjang pembelajaran membuat siswa kurang termotivasi untuk belajar.

Pada saat dilakukan analisis, kurikulum yang digunakan sekolah adalah kurikulum tingkat satuan pendidikan dan menerapkan SK-KD sesuai dengan standar isi. SMAN 2 Jombang menerapkan kurikulum 2013, sehingga modul yang 
dikembangkan menggunakan kurikulum 2013.

2. Tahap Perancangan (Design)

Tahap perencanaan dan pembuatan modul dilakukan identifikasi materi pokok pembelajaran dan tujuan kegiatan pembelajaran untuk memperoleh gambaran yang akan dimasukkan ke dalam modul fisika berbasis inkuiri terbimbing. Pemilihan format sesuai dengan format kriteria modul yang diadaptasi dari Modul berbasis inkuiri terbimbing merupakan suatu rangkaian kegiatan belajar yang melibatkan secara maksimal seluruh kemampuan siswa untuk menganalisis, memecahkan permasalahan berdasarakan fakta-fakta yang ditemukan dan didesain untuk mendapatkan pemahaman konseptual (Rusche \& Jason,2011). Modul inkuiri terbimbing menggunakan sintaks inkuiri terbimbing: 1) observasi; 2) Merumuskan masalah;3) Mengidentifika masalah, penjabaran aspek fisikanya, rencana pemecahan masalah, menjalankan rencana pemecahan masalah, dan mengevaluasi jawaban. Modul pembelajaran dirancang dengan materi dinamika gerak dengan tahapan pembelajaran sesuai dengan sintak pembelajaran inkuiri terbimbing yang telah dirumuskan dalam silabus dan RPP. Pemilihan format modul pembelajaran dilakukan berdasarkan format dengan mengkaji kriteria modul pembelajaran fisika yang diterbitkan oleh Depdiknas. Pada tahapan desain dan pembuatan modul yang disusun dengan konsultasi pada dosen pembimbing, didapat produk awal berupa draf I terdiri dari silabus, RPP, kisi-kisi soal, dan modul hasil pengembangan. Desain menurut Oemar Hamalik cit Daryanto (2010: 16) yaitu suatu petunjuk yang memberikan dasar, arah, tujuan, dan teknik yang ditempuh dalam memulai dan melaksanakan suatu kegiatan. Kedudukan desain dalam pengembangan modul yaitu sebagai salah satu komponen prinsip pengembangan modul yang mendasari dan memberi arah teknik dan tahapan penyusunan modul.
Modul dikembangkan melalui tiga tahap yaitu perancangan, pengumpulan bahan dan materi, dan penyusunan. Pada tahap perancangan modul ditentukan spesifikasinya, kemudian dibuat rencana format desain. Tahap ini didukung oleh Microsoft Word 2007. Tahap pengumpulan bahan dan materi yang berasal dari beberapa sumber, seperti buku-buku rujukan, situs pendidikan, makalah dan gambar-gambar pendukung. Tahap penyusunan dilakukan ketika bahan dan materi sudah terkumpul.

3. Validasi Modul

Validasi dilakukan dengan menggunakan instrumen lembar validasi silabus, lembar validasi RPP, lembar validasi kisi-kisi soal dan lembar validasi modul pembelajaran hasil pengembangan. Menurut Daryanto (2010: 23) validasi dilakukan dengan cara meminta bantuan ahli yang menguasai kompetensi yang dipelajari.

Validasi menghasilkan draf II dari produk pengembangan. Validasi dilakukan oleh 2 pakar atau dosen ahli dari Universitas Sebelas Maret, 2 orang guru fisika yaitu 1 guru fisika SMAN 1 Ngoro dan 1 guru fisika SMAN 2 Jombang, serta 2 teman sejawat. Validator yang terlibat meliputi dosen pakar validator 1 (V1) dan validator 2 (V2), validator guru SMA, guru validator 1 (G1) dan guru validator 2 (G2), serta 2 teman sejawat terdiri dari teman sejawat 1 (S1) dan teman sejawat 2 (S2). Hasil penilaian validasi draf I disajikan pada tabel 1 sampai tabel 2 .

Tabel 1. Hasil Validasi oleh Ahli

\begin{tabular}{|c|c|c|}
\hline Validator ke & Jumlah & Kategori \\
\hline I & 228 & Sangat baik \\
\hline II & 230 & Sangat baik \\
\hline Nilai keseluruhan & 458 & Sangat baik \\
\hline
\end{tabular}
modul yang dilakukan oleh ahli adalah: ahli 1 dan untuk ahli 2. Kategori nilai tersebut adalah "sangat baik". Kedua validator ahli juga menyatakan bahwa modul fisika berbasis Inkuiri terbimbing yang dikembangkan ini valid dan layak digunakan. 
Tabel 2. Hasil Respon dari Teman Sejawat dan Guru Fisika

\begin{tabular}{clccc}
\hline \multirow{2}{*}{ Reviewer } & Jumlah & $\begin{array}{c}\text { Jumlah } \\
\text { keseluruhan }\end{array}$ & Kategori \\
\cline { 1 - 2 } Guru & I 223 & 432 & SB \\
\cline { 2 - 2 } & II 209 & 461 & SB \\
\cline { 1 - 2 } $\begin{array}{c}\text { Teman } \\
\text { Sejawat }\end{array}$ & I 229 & II 232 & 432 & \\
\hline \multicolumn{2}{c}{ Berdasarkan } & Tabel 2, & hasil
\end{tabular}

Berdasarkan Tabel 2, hasil respon dari 2 guru fisika SMA menberikan kategori sangat baik. Sedangkan untuk teman sejawat, hasil respon dari 2 teman sejawat masing - masing menberikan . kategori sangat baik.

Validator dan reviewer juga memberikan saran perbaikan gambar cover, gambar kurang jelas, font sesuai ejaan EYD, konsisten dalam penulisan dalam kegiatan belajar. Setelah dilakukan perbaikan, tahap ini menghasilkan draf II modul fisika berbasis Inkuiri Terbimbing.

4. Uji Coba Terbatas

Uji coba terbatas dilaksanakan pada tanggal 7 Nopember 2015 di laboraturium SMAN 2 Jombang Jawa Timur pada kelas $\mathrm{X}_{5}$ yang terpilih sebagai sampel uji coba penelitian. Uji coba terbatas dilakukan untuk mengetahui tingkat keterbacaan siswa pada modul pembelajaran fisika berbasis Inkuiri Terbimbing pada materi dinamika gerak hasil pengembangan. Tingkat keterbacaan siswa terhadap modul diketahui melalui respon siswa terkait modul pembelajaran fisika berbasis Inkuiri Terbimbing hasil pengembangan, siswa diminta mengisi angket respon siswa. Sebelum mengisi angket respon siswa, pastikan siswa telah mempelajari modul dan melakukan tahapan-tahapan kegiatan pembelajaran yang terdapat dalam modul. Uji coba terbatas dilakukan 10 siswa untuk membaca dan melakukan kegiatan yang terdapat dalam modul serta mengisi angket respon yang disediakan. Hal ini sesuai dengan pendapat Dick dan Carey (2005:291) bahwa jumlah yang diperlukan dalam evaluasi kelompok kecil hanya terdiri dari delapan sampai sepuluh orang.

Adapun hasil persentase angket respon secara umum pada tabel 3 .
Tabel 3. Hasil Uji Coba Kelompok Kecil

\begin{tabular}{lcc}
\hline \multicolumn{1}{c}{ Aspek } & Skor & Kategori \\
\hline $\begin{array}{l}\text { Kelayakan Modul } \\
\text { keseluruhan }\end{array}$ & 77 & SB \\
\hline Aspek Kelayakan penyajian & 80 & SB \\
\hline Aspek Kegrafikan & 80 & SB \\
\hline Aspek isi & 73 & B \\
\hline $\begin{array}{l}\text { Aspek kesesuaian dengan } \\
\text { pembelajaran inkuiri } \\
\text { terbimbing }\end{array}$ & 78 & SB \\
\hline
\end{tabular}

Tabel 3 menyajikan rangkuman hasil uji coba terbatas yang telah dilakukan. menunujukkan bahwa angket respon yang diberikan kepada siswa terkait modul pembelajran berbasis Inkuiri Terbimbing, secara keseluruhan mendapat respon yang sangat baik.

5. Uji Coba Diperluas

Uji coba dilaksanakan mulai tanggal 12 Nopember 2015 sampai 25 Nopember 2015. Uji coba pemakaian di kelas dilaksanakan pada siswa kelas X-6 di SMAN 2 Jombang Kabupaten Jombang. Sebelum modul pembelajaran fisika berbasis Inkuiri Terbimbing diimplementasikan dalam pembelajaran, terlebih dahulu siswa diberikan pretest. Soal pretest terdiri dari 15 butir soal pilihan ganda dan dilaksanakan pada tanggal 11 Nopember 2015 yang diikuti 30 siswa. Soal yang digunakan telah divalidasi oleh dua dosen ahli, dua guru fisika, dan dua peer review atau teman sejawat, kemudian soal yang berjumlah 20 butir diuji reliabilitas dan dilakukan analisis butir instrumen menggunakan uji daya pembeda dan tingkat kesukaran pada 34 siswa kelas X-5 Jombang. Dari 20 butir soal yang diujicobakan diperoleh soal yang baik sebanyak 15 soal digunakan untuk uji tes pada uji coba pemakaian yaitu pada pretest dan protest. Setelah dilakukan pretest, siswa diberikan modul fisika berbasis Inkuiri Terbimbing. Modul fisika berbasis Inkuiri Terbimbing digunakan sebagai modul inti dalam proses pembelajaran di kelas. Setelah materi pembelajaran selesai, kemudian siswa diberikan soal posttest. Hasil pretest dan posttest disajikan pada Tabel 4. 
Tabel 4 Perbandingan persentase siswa yang mengalami miskonsepsi sebelum dan sesudah pelakuan pembelajaran berbasis inkuiri terbimbing

\begin{tabular}{|c|c|c|c|}
\hline \multirow{2}{*}{ Sumber miskonsepsi } & \multicolumn{3}{|c|}{ Persentase } \\
\hline & Awal & Akhir & $(+) /(-)$ \\
\hline $\begin{array}{l}\text { Jika benda bergerak } \\
\text { searah dengan gaya } \\
\text { penyebab gerak benda } \\
\text { pasti gaya tersebut } \\
\text { lebih besar dari gaya } \\
\text { yang melawan }\end{array}$ & 50,0 & 23,3 & 26.7 \\
\hline $\begin{array}{l}\text { Jika benda bergerak } \\
\text { searah dengan gaya } \\
\text { penyebab gerak benda } \\
\text { pasti gaya tersebut } \\
\text { lebih besar dari gaya } \\
\text { yang melawan }\end{array}$ & 30,0 & 30,0 & 0,0 \\
\hline $\begin{array}{l}\text { Gayadi perlukan untuk } \\
\text { mempertahankan } \\
\text { benda yang bergerak }\end{array}$ & 60.0 & 40,0 & 20,0 \\
\hline $\begin{array}{l}\text { Gaya di perlukan } \\
\text { untuk } \\
\text { mempertahankan } \\
\text { benda yang bergerak }\end{array}$ & 70,0 & 33,3 & 36,7 \\
\hline $\begin{array}{l}\text { Percepatan gerak } \\
\text { benda berbanding lurus } \\
\text { dengan massa benda }\end{array}$ & 40,0 & 6,7 & 33,3 \\
\hline $\begin{array}{l}\text { Percepatan gerak } \\
\text { benda berbanding lurus } \\
\text { dengan massa benda }\end{array}$ & 50,0 & 20,0 & 30,0 \\
\hline $\begin{array}{l}\text { Berat benda = massa } \\
\text { benda }\end{array}$ & 56,6 & 40,0 & 16,6 \\
\hline $\begin{array}{llr}\text { Gaya } & \text { normal } & \text { selalu } \\
\text { sejajar } & \text { dengan } & \text { sumbu } \\
\text { Y } & & \\
\end{array}$ & 43,3 & 40,0 & 3,3 \\
\hline $\begin{array}{l}\text { Gaya aksi-reaksi besar } \\
\text { sama, berlawanan arah } \\
\text { bekerja pada benda } \\
\text { yang berbeda (tanpa } \\
\text { memperhatikan titik } \\
\text { kerja) }\end{array}$ & 43,3 & 40,0 & 13,3 \\
\hline $\begin{array}{l}\text { Gaya aksi-reaksi besar } \\
\text { sama, berlawanan arah } \\
\text { bekerja pada benda } \\
\text { yang berbeda (tanpa } \\
\text { memperhatikan titik } \\
\text { kerja). }\end{array}$ & 46,7 & 43,3 & 3,4 \\
\hline $\begin{array}{l}\text { Tidak ada jaminan besar } \\
\text { gaya aksi-rekasi sama } \\
\text { dengan besar gaya } \\
\text { reaksi }\end{array}$ & 33,3 & 23,3 & 10 \\
\hline $\begin{array}{l}\text { Tidak ada jaminan besar } \\
\text { gaya aksi-rekasi sama } \\
\text { dengan besar gaya } \\
\text { reaksi }\end{array}$ & 43,3 & 23,3 & 20 \\
\hline $\begin{array}{l}\text { Jika benda di dorong } \\
\text { tapi tetap diam, maka } \\
\text { gaya dorong lebih } \\
\text { kecil dari pada gaya } \\
\text { gesekan }\end{array}$ & 40,0 & 26,7 & 13,3 \\
\hline $\begin{array}{l}\text { Jika benda di dorong } \\
\text { tapi tetap diam, maka } \\
\text { gaya dorong lebih } \\
\text { kecil dari pada gaya }\end{array}$ & 33,3 & 20,0 & 13,3 \\
\hline
\end{tabular}

\begin{tabular}{lccc}
\hline \multirow{2}{*}{ Sumber miskonsepsi } & \multicolumn{3}{c}{ Persentase } \\
\cline { 2 - 4 } & Awal & Akhir & $(+) /(-)$ \\
\hline gesekan & & & \\
& & & \\
\hline $\begin{array}{l}\text { Jika benda di dorong } \\
\text { tapi tetap diam, maka } \\
\text { gaya dorong lebih } \\
\text { kecil dari pada gaya } \\
\text { gesekan }\end{array}$ & 70,0 & 43,3 & 26,7 \\
\hline
\end{tabular}

Tabel 4 Ada beberapa soal yang perlu diperhatikan terkait dengan penurunan miskonsepsi yang diperoleh. Tingkat penurunan miskonsepsi pada soal nomor 2, 8 , dan 10 kurang dari $10 \%$. Alasan logis perolehan ini didasarkan pada jumlah jawaban salah dan CRI yang diberikan siswa. Pada postes ketiga soal tersebut, jumlah siswa yang menjawab salah telah berkurang, tetapi mereka memberikan CRI yang lebih tinggi dari pretes. Akibatnya, perhitungan menyimpulkan adanya penurunan yang kecil.

Karena miskonsepsi naik pada soal nomor 2,8 dan nomor 10, perlu dilakukan analisis lebih mendalam mengenai perbandingan pengetahuan siswa pada saat pretes dan postes.

Tabel 5 Perbandingan pengetahuan siswa pada saat pretes dan postes nomor 2

\begin{tabular}{llll}
\hline Pretes & Postes & $\begin{array}{l}\text { Jum } \\
\text { lah }\end{array}$ & No Absen \\
\hline TK & TK & 1 & 24 \\
\hline TTK & TK & 7 & $4,7,8,15,19,27,30$ \\
\hline MK & TK & 9 & $\begin{array}{l}5,11,13,14,16,21,22,23,2 \\
\end{array}$ \\
\hline MK & MK & 6 & $6,9,12,20,25,26$ \\
\hline TTK & MK & 2 & 1,18 \\
\hline TK & MK & 2 & 10,29 \\
\hline TTK & TTK & 3 & $2,3,17$ \\
\hline
\end{tabular}

Berdasarkan tabel tersebut, dapat dipaparkan bahwa modul pembelajaran berbasis inkuiri terbimbing memiliki pengaruh yang berbeda pada beberapa siswa. Dari siswa yang awalnya miskonsepsi (MK) sebanyak 9 siswa, modul pembelajaran berbasis inkuiri terbimbing mampu menurunkan 30\% menjadi 9 siswa menjadi tahu konsep (TK). Perubahan dari tidak tahu konsep (TTK) menjadi miskonsepsi (MK) sebanyak 2 
siswa membuktikan bahwa siswa yang menjawab salah menaikkan CRI-nya. Siswa memberikan CRI yang naik karena berpikir bahwa keyakinan harus meningkat setelah pembelajaran, baik jawaban salah maupun benar. Perubahan dari tahu konsep (TK) menjadi miskonsepsi (MK) sebanyak 2 orang menunjukkan bahwa keterlaksanaan modul pembelajaran berbasis inkuiri terbimbing perlu diperbaiki dan disempurnakan. Miskonsepsi (MK) 9 siswa tidak berubah pada pretes dan postes membuktikan adanya miskonsepsi yang permanen pada soal ini sehingga sulit diperbaiki.

Tabel 6 Perbandingan pengetahuan siswa pada saat pretes dan postes nomor 8

\begin{tabular}{cccc}
\hline Pretes & Postes & Jumlah & No Absen \\
\hline TK & TK & 0 & - \\
\hline TTK & TK & 6 & $5,9,10,14,15,21$ \\
\hline MK & TK & 6 & $11,13,16,22,25,28$ \\
\hline MK & MK & 6 & $2,7,8,20,24,29$ \\
\hline TTK & MK & 6 & $4,18,19,26,30,23$ \\
\hline TK & MK & 2 & 1,6 \\
\hline TTK & TTk & 4 & $3,12,17,27$ \\
\hline
\end{tabular}

Berdasarkan Tabel 6 di atas, seperti halnya dengan soal nomor 8 , perubahan dari tidak tahu konsep (TTK) menjadi miskonsepsi (MK) sebanyak 6 siswa membuktikan bahwa siswa yang menjawab salah menaikkan CRI-nya. Perubahan dari tahu konsep (TK) menjadi miskonsepsi (MK) sebanyak 2 orang menunjukkan bahwa keterlaksanaan modul pembelajaran berbasis inkuiri terbimbing perlu diperbaiki dan disempurnakan. Miskonsepsi (MK) 6 siswa tidak berubah pada pretes dan postes membuktikan yang permanen pada soal ini sehingga sulit diperbaiki. Miskonsepsi (MK) yang awalnya berjumlah 13 siswa hanya turun $40 \%$, artinya hanya 6 siswa yang berubah menjadi tahu konsep (TK). Hal ini juga disebabkan tingkat kerumitan soal yang lebih tinggi soal-soal sebelumnya.

Tabel 7 Perbandingan pengetahuan siswa pada saat pretes dan postes nomor 10

\begin{tabular}{cccl}
\hline Pretes & Postes & Jumlah & \multicolumn{1}{c}{ No Absen } \\
\hline TK & TK & 1 & 2 \\
\hline TTK & TK & 5 & $4,5,14,23,26$ \\
\hline MK & TK & 3 & $3,11,24$ \\
\hline
\end{tabular}

\begin{tabular}{cccl}
\hline Pretes & Postes & Jumlah & \multicolumn{1}{c}{ No Absen } \\
\hline MK & MK & 5 & $5,12,16,18,28$ \\
\hline TTK & MK & 6 & $1,15,20,28,29,30$ \\
\hline TK & MK & 5 & $6,8,9,10,19$ \\
\hline TTK & TTk & 5 & $25,22,21,13,9$ \\
\hline
\end{tabular}

Berdasarkan Tabel 7 di atas, seperti halnya dengan soal nomor 10, perubahan dari tidak tahu konsep (TTK) menjadi miskonsepsi (MK) sebanyak 6 siswa membuktikan bahwa siswa yang menjawab salah menaikkan CRI-nya. Perubahan dari tahu konsep (TK) menjadi miskonsepsi (MK) sebanyak 5 orang menunjukkan bahwa keterlaksanaan modul pembelajaran berbasis inkuiri terbimbing perlu diperbaiki dan disempurnakan. Miskonsepsi (MK) 5 siswa tidak berubah pada pretes dan postes membuktikan yang permanen pada soal ini sehingga sulit diperbaiki. Miskonsepsi (MK) yang awalnya berjumlah 14 siswa hanya turun $43,3 \%$, artinya hanya 3 siswa yang berubah menjadi tahu konsep (TK). Hal ini juga disebabkan tingkat kerumitan soal yang lebih tinggi soal-soal sebelumnya Analisis data pretest dan postest dilakukan melalui tahap uji prasyarat terlebih dahulu yaitu uji normalitas dan homogenitas. Jika data normal dan homogen maka uji selanjutnya menggunakan uji parametrik, tetapi jika data tidak normal dan homogen maka dilakukan uji non prametrik.

Uji normalitas digunakan untuk mengetahui data berdistribusi normal atau tidak, sedangkan uji homogenitas digunakan untuk mengetahui kesamaan variansi data. Uji normalitas dan homogenitas menggunakan program SPSS 18. Analisis statistik untuk uji normalitas menggunakan uji Kolmogorov-sminov a dan uji homogenitas menggunakan uji Lavene's test. Hasil analisis disajikan pada tabel 5 .

\begin{tabular}{ccccl}
\multicolumn{4}{c}{ Tabel 5. Analisis Normalitas dan Homogenitas } \\
\hline No & $\begin{array}{l}\text { Yang } \\
\text { Di uji }\end{array}$ & Jenis Uji & Sig & Keputusan \\
& & Korma & Kolmogorov- \\
sminov & 0,200 & $\begin{array}{l}\text { Ho }= \\
\text { diterima }\end{array}$ \\
\hline $\mathbf{2}$ & $\begin{array}{l}\text { Homo- } \\
\text { genitas }\end{array}$ & Lavene's test & 0,389 & $\begin{array}{l}\text { Ho }= \\
\text { diterima }\end{array}$ \\
\hline
\end{tabular}

Berdasarkan hasil pada Kolmogorovsminov $^{\mathrm{a}}$ untuk nilai pretest diperoleh 
signifikansi 0,200 yang berarti nilai signifikansinya kurang dari 0,05 . Sehingga $\mathrm{H}_{0}$ diterima, kesimpulannya nilai ujian tengah semester berdistribusi normal.

Berdasarkan uji Lavene's test, didapatkan signifikansi 0,389 yang berarti nilai signifikansinya lebih dari 0,05 sehingga Ho diterima, kesimpulannya variansi data homogen. Hasil uji normalitas dan homogenitas menunjukkan bahwa sebaran data tidak terdistribusi normal dan bersifat homogen,

penyajian, kegrafikan, isi, dan kesesuaian dengan pembelajaran inkuiri terbimbing masing- masing mendapatkan respon sangat baik. Hasil respon siswa ini menunujukkan bahwa modul fisika berbasis inkuiri terbimbing dengan materi dinamika gerak yang dikembangkan layak untuk digunakan. Tahapan selanjutnya yaitu dilaksanakan tahap Disseminate (penyebaran) agar diperoleh saran dan masukan terhadap modul hasil pengembangan.

6. Tahap Penyebaran (Disseminate)

Pada tahap penyebaran, modul

fisika berbasis inkuiri terbimbing ving materi dinamika gerak disebarkan ke 10 guru fisika SMA di kabupaten Jombang. Penyebaran modul seharusnya dilakukan pada forum MGMP, tetapi karna tidak ada agenda kegiatan guru MGMP di kabupaten Jombang maka penyebaran dilakukan pada sekolah-sekolah SMA di kabupaten Jombang. Penyebaran dilakukan pada 4 guru fisika SMAN 2 Jombang, 2 guru fisika SMAN 3 Jombang, 1 guru fisika SMAN 1 Ngoro, 1 guru fisika SMAN 1 Mojoagung, dan 2 guru fisika SMAN 1 Jogoroto. Setelah diberikan modul fisika berbasis inkuiri terbimbing materi elastisitas, guruguru diberikan angket untuk mengetahui respon guru-guru terhadap modul yang telah dikembangkan. Respon guru-guru terhadap modul fisika berbasis inkuiri terbimbing materi dinamika gerak disajikan pada tabel 8 .
Tabel 8. Respon Guru Fisika Terhadap Modul Fisika Berbasis inkuiri terbimbing

\begin{tabular}{|c|c|c|}
\hline Aspek & Skor $(\%)$ & Kategori \\
\hline Kelayakan Modul Keseluruhan & 94 & SB \\
\hline Kelayakan penyajian & 95 & SB \\
\hline Kegrafikan & 96 & SB \\
\hline Isi & 93 & SB \\
\hline $\begin{array}{ll}\text { Kesesuaian } & \text { dengan } \\
\text { pembelajaran problem solving }\end{array}$ & 90 & SB \\
\hline
\end{tabular}

Tabel 8. menunjukkan bahwa angket respon yang diberikan kepada 10 guru terkait modul pembelajaran yang telah diberikan, secara keseluruhan modul mendapatkan respon sangat baik. Aspek dari modul meliputi aspek isi, aspek bahasa, aspek kegrafikan, aspek kelayakan penyajian, aspek kesesuaian dengan pembelajaran inkuiri terbimbing masingmasing mendapatkan respon sangat baik. Dari hasil perolehan respon guru dalam kategori sangat baik sehingga dapat dinyatakan bahwa modul berbasis inkuiri terbimbing dengan materi elastisitas yang dikembangkan layak untuk digunakan.

\section{Kesimpulan dan Rekomendasi}

Langkah-langkah pengembangan yang dilakukan untuk mengembangkan modul fisika berbasis inkuiri terbimbing materi Dinamika adalah melakukan studi literatur yang meliputi analisis siswa, kurikulum dan materi, pemilihan format modul, desain awal modul, validasi produk, uji coba terbatas, perbaikan, uji coba pemakaian, dan penyebaran modul pada guru MGMP. Pengembangan yang dilakukan mengacu pada langkah yang dinyatakan oleh Thiangarajan dan telah tervalidasi. Modul fisika berbasis inkuiri terbimbing materi dinamika gerak untuk siswa kelas X SMA yang dikembangkan dinyatakan layak berdasarkan indikator kelayakan media baik dari segi kelayakan isi, maupun kelayakan kegrafikan, serta daya tarik yang berada pada kategori sangat baik. Pencapaian hasil belajar peserta didik setelah mengikuti proses pembelajaran menggunakan modul fisika berbasis inkuiri terbimbing mengalami penurunan miskonsepsi. 
Berdasarkan hasil penelitian yang telah dilakukan, maka diajukan beberapa saran sebagai berikut: (1) Bagi guru, pemanfaatan produk berupa modul fisika berbasis inkuiri terbimbing oleh guru secara maksimal dan membantu guru untuk mengembangkan modul atau bahan ajar dengan tema yang lain. Berdasarkan uji coba lapangan, pembelajaran dengan menggunakan modul fisika berbasis inkuiri terbimbing dapat meningkatkan hasil belajar siswa dan siswa merasa senang. (2) Bagi peneliti berikutnya, Penelitian ini mengembangkan modul fisika inkuiri terbimbing pada materi dinamika gerak, peneliti berikutnya disarankan mengembangkan modul fisika dengan materi yang lain. Penelitian pengembangan modul fisika berbasis inkuiri terbimbing materi dinamika gerak materi untuk siswa kelas X SMA diharapkan memacu peneliti selanjutnya untuk selalu melakukan inovasi dalam pembelajaran, serta mengikuti perkembangan sains.

\section{Daftar Pustaka}

Arifin, Zainal. (2012). Evaluasi Pembelajaran. Bandung: Remaja Rosdakarya.

Berg, Euwe Van Den.1991. Miskonsep Fisika dan Remidiasi salatiga. Universitas Kristen Satya Wacana

Budiyono. (2011). Penilaian Hasil Belajar. Surakarta: Pascasarjana UNS.

Daryanto. (2010). Belajar dan Mengajar. Bandung: Yrama Widya

Departemen Pendidikan Nasional 2013. Badan Standart Nasional Pendidikan (BSNP). ( on line) 20 juni 2014

Dick, W. Cary. And Carey, J.O. (2005). The Systematic Design of Instruction. Boston: Omegatype Typography, Incoperation.

Hamdani. (2011). Strategi Belajar Mengajar. Bandubg: Pustaka Setia

\footnotetext{
Ibrahim, Muslimin. 2012. Konseps Miskonsepsi, dan cara pembelajarannya Surabaya: UNESA University Press.
}

Riduwan. (2004). Belajar Mudah Penelitian untuk Guru, Karyawan, dan Peneliti Muda. Bandung.

Sugiyono. (2011). Metode Penelitian Kuantitatif, Kualitatif, dan $R \& D$. Bandung: Alfabeta.

-(2012). Statistika untuk Penelitian. Bandung: Alfabeta.

Sani, Abdulah S. 2014. Pembelajaran Sainstifik Untuk Implementasi Kurikulum 2013.Jakarta: Bumi Aksara.

Suparno,Paul 2005. Miskonsepsi dan Perubahan Konsep Pendidikan Fisika Jakarta: PT Grasindo

2007 Metodologi Pembelajaran Fisika, Yogyakarta : Universitas Sanata Dharma Press.

Thiagarajan \& Semmel. (1974). Instructional development for training teacher of exceptional children. Bloomington Indiana: Indiana University. 